Volume 1 Issue 2, September 2017: pp. 196-219. Copyright (c) 2017 HOLREV. Faculty of Law, Halu Oleo University, Kendari, Southeast Sulawesi, Indonesia. ISSN: 2548-1762 | e-ISSN: 2548-1754. Open Access at: http://ojs.uho.ac.id/index.php/holrev/

\title{
Bayi Tabung (Fertilisasi In Vitro) Dengan Menggunakan Sperma Donor dan Rahim Sewaan (Surrogate Mother) dalam Perspektif Hukum Perdata
}

\author{
In Vitro Fertilization (IVF) by Processing Donor Sperm and Surrogate \\ Mother in Civil Law Perspectives
}

\author{
Zahrowati \\ Fakultas Hukum Universitas Halu Oleo Kendari \\ E-mail: zahrowati.s3@gmail.com
}

\begin{abstract}
This study aimed at to know the legal standing of born child through the IVF process using donor sperm and rented uterus (surrogate mother) in a civil law perspective. This paper is implementing normative method. The approach which is used ini this writing namely legislation approach (Statute Approach). The result of writing that in the concept of civil law, the children which is born through the IVF process by using donor sperm was qualified and positioned as legitimate child as if he/she earned recognizance (article 280 of the civil code). Subsequently the children which is born through IVF process by using rented uterus (surrogate mother) qualified as adopted children (article 8 Stb. 1917/129).
\end{abstract}

Keyword: fertilization in fitro, IVF, donor sperm, rented uterus, civil law

Abstrak: Penulisan ini bertujuan untuk mengetahui kedudukan hukum anak yang dilahirkan melalui proses bayi tabung (fertilisasi in vitro) dengan menggunakan sperma donor dan rahim sewaan (surrogate mother) dalam perspektif Hukum Perdata. Penulisan ini menggunakan metode penulisan normatif, pendekatan yang digunakan dalam penulisan ini adalah pendekatan undang-undang (Statute Approach). Hasil penulisan diperoleh kesimpulan bahwa dalam konsep KUHPerdata, anak yang dilahirkan melalui proses bayi tabung dengan menggunakan sperma donor berkedudukan sebagai anak sah apabila memperoleh pengakuan (Pasal 280 KUHPerdata), kemudian anak yang dilahirkan melalui proses bayi tabung dengan menggunakan rahim sewaaan (surrogate mother) berkedudukan sebagai anak angkat (Pasal 8 Stb. 1917/129).

Kata kunci: Bayi tabung, sperma donor, rahim sewaan. 


\section{PENDAHULUAN}

Kehadiran seorang anak dalam keluarga memberikan sebuah arti yang berbeda, tempat mencurahkan kasih sayang, sebagai penerus garis keturunan dan dapat menunjang kepentingan dunia dan akhirat bagi kedua orang tuanya. Keberadaan anak dalam keluarga merupakan sesuatu yang sangat berarti. Anak memiliki arti yang bermakna bagi setiap orang. Anak merupakan penyambung keturunan, sebagai investasi masa depan, dan anak merupakan harapan untuk menjadi sandaran di kala usia lanjut. Ia dianggap sebagai modal untuk meningkatkan peringkat hidup sehingga dapat mengontrol status sosial orang tua. Anak merupakan pemegang keistimewaan orang tua, waktu orang tua masih hidup, anak sebagai penenang dan sewaktu orang tua telah meninggal, anak adalah lambang penerus dan lambang keabadian. Anak mewarisi tanda-tanda kesamaan dengan orang tuanya, termasuk ciri khas, baik maupun buruk, tinggi, maupun rendah. Anak adalah belahan jiwa dan potongan daging orang tuanya. ${ }^{1}$

Begitu pentingnya kehadiran seorang anak di dalam keluarga sehingga setiap pasangan suami-istri selalu menginginkan kehadirannya. Tetapi, pada kenyataannya tidak semua pasangan suami-istri dapat memperoleh keturunan secara normal. Banyak ditemui di lapangan bahwa, setelah sekian lama menikah pasangan suami-istri belum juga mendapatkan keturunan walaupun sudah berusaha dengan berbagai cara.

Hasil penelitian, apabila dipresentasikan dalam bentuk angka kurang lebih 10\% dari pasangan suami istri tidak dikaruniai keturunan (infertile), sedangkan kecil kemungkinan bagi mereka melakukan adopsi anak. Penyebab infertilitas ini kira-kira 40\% karena kelainan pada pria, 15\% karena kelainan pada leher rahim, 10\% karena kelainan pada rahim, 30\% karena kelainan pada saluran telur dan kelainan peritoneal, 20\% kelainan pada ovarium, dan 5\% karena hal lain-lain, dan kejadian totalnya melebihi 100\%, karena pada kira-kira 35\% pada suami istri terdapat kelainan yang multiple. ${ }^{2}$

Dewasa ini, ilmu dan teknologi di bidang kedokteran mengalami perkembangan yang sangat pesat serta memberikan dampak positif bagi manusia yaitu dengan ditemukannya cara-cara baru dalam memberi jalan keluar bagi pasangan suami-istri yang tidak dapat memperoleh anak secara alami yang dalam istilah kedokteran disebut dengan Fertilisasi In Vitro atau lebih populer dengan istilah Bayi Tabung.

Yusuf Al Qadhawi, Halal dan Haram dalam Islam, Surabaya: PT. Bina Ilmu, 1976, h. 256.

2 Idries AM, Aspek Medikolegal Pada Inseminasi Buatan/Bayi Tabung, ED. I Jakarta: Bina Rupa Aksara. 
Secara bahasa Fertilisasi In Vitro terdiri dari dua suku kata yaitu Fertilisasi dan In Vitro. Fertilisasi berarti pembuahan sel telur wanita oleh spermatozoa pria, In Vitro berarti di luar tubuh. Dengan demikian, fertilisasi in vitro berarti proses pembuahan sel telur wanita oleh spermatozoa pria (bagian dari proses reproduksi manusia), yang terjadi di luar tubuh. ${ }^{3}$

Sebagian penyebab infertilitas dapat diatasi dengan pengobatan maupun operasi, sedangkan infertilitas yang disebabkan karena kegagalan inseminasi, pembuahan, fertilitas, kehamilan, persalinan dan kelahiran hidup normal, ternyata dapat diatasi dengan cara buatan (artificial). Cara-cara tersebut antara lain: Inseminasi buatan (artificial insemination/AI), pembuahan dalam (artificial conception/AC), penyuburan/pembuahan dalam (in vitro fertilitzation/IVF), pemindahan janin/penanaman janin (embriyo transfer/embriyo transplant/ET). ${ }^{4}$

Metode bayi tabung dapat dilakukan dengan 7 (tujuh) cara. Ketujuh cara tersebut adalah sebagai berikut ${ }^{5}$ :

1. Sel sperma suami disuntikkan langsung ke sel telur (ovum) istri;

2. Sel sperma berasal dari suami, sel telur (ovum) berasal dari istri kemudian ditanamkan ke dalam rahim istri;

3. Sel sperma berasal dari donor, sel telur (ovum) berasal dari istri kemudian ditanamkan ke dalam rahim istri;

4. Sel sperma berasal dari suami, sel telur (ovum) berasal dari donor kemudian ditanamkan ke dalam rahim istri;

5. Sel sperma berasal dari donor, sel telur (ovum) berasal dari donor kemudian ditanamkan ke dalam rahim istri;

6. Sel sperma berasal dari suami, sel telur (ovum) berasal dari istri kemudian ditanamkan ke dalam rahim wanita lain (rahim sewaan);

7. Sel sperma berasal dari suami, sel telur (ovum) berasal dari istri kemudian ditanamkan ke dalam rahim istri lainnya.

3 Wiryawan Permadi et al, Hanya 7 Hari Memahami Fertilisasi In Vitro, Bandung: PT Refika Aditama, 2008, h. 1 .

4 Husni Thamrin, Aspek Hukum Bayi Tabung. Jogyakarta: Aswaja Pressindo

5 Sri Wahyuni, "Status Hak Waris Anak Luar Kawin Menurut KHI", h. 10, http://eprints.undip.ac.id/15327/1/sri wahyunib4b004176.pdf, dikunjungi pada tanggal 22 September 2011. 
Hakikatnya proses bayi tabung bertujuan untuk membantu pasangan suami istri yang tidak mampu melahirkan keturunan secara alami yang disebabkan karena ada kelainan pada tubanya, yaitu: endometriosis (radang pada selaput lendir rahim), oligospermia (sperma suami kurang baik), unexplained infertility (tidak dapat diterangkan sebabnya) dan adanya faktor immunologic (faktor kekebalan). Ternyata proses bayi tabung ini mampu memberikan salah satu solusi bagi pasangan suami-istri dalam memperoleh keturunan pada perkawinan yang sah menurut peraturan yang berlaku.

Pada mulanya program fertilisasi in vitro ini dapat diterima olek khalayak umum, namun mulai dipertentangkan. Banyak pihak yang pro dan kontra dengan program ini, sedangkan persoalan lainnya pada bidang hukum, dikarenakan belum tersedianya peraturan perundang-undangan yang mengatur tentang kedudukan hukum anak yang dilahirkan melalui proses bayi tabung.

Hukum positif Indonesia yang mengatur tentang kedudukan hukum seorang anak diatur di dalam KUH Perdata, UU Nomor 1 Tahun 1974 tentang Perkawinan, dan Kompilasi Hukum Islam. Di dalam ketiga aturan tersebut tidak ada suatu ketentuan yang mengatur secara tegas tentang kedudukan hukum anak yang dilahirkan melalui proses bayi tabung yang spermanya berasal dari donor dan ovumnya berasal dari istri kemudian embrionya ditanamkan ke dalam rahim istri maupun yang menggunakan sperma dan ovum dari pasangan suami-istri kemudian embrionya ditanamkan ke rahim sewaan (surrogate mother), yang ada hanyalah mengatur tentang pengertian anak sah, pengesahan anak luar kawin, dan pengakuan terhadap anak luar kawin.

Pengertian anak sah diatur di dalam Pasal 250 KUH Perdata, Pasal 42 UU Nomor 1 Tahun 1974, dan Pasal 99 KHI. Pasal 250 KUH Perdata "Tiap-tiap anak yang dilahirkan atau ditumbuhkan sepanjang perkawinan memperoleh si suami sebagai bapaknya". Kemudian di dalam Pasal 42 UU Nomor 1 Tahun 1974 disebutkan bahwa "Anak sah adalah anak yang dilahirkan dalam atau sebagai akibat dari perkawinan yang sah". Selanjutnya di dalam Pasal 99 KHI dijelaskan bahwa "Anak sah adalah (a) anak yang dilahirkan dalam atau akibat perkawinan yang sah dan (b) hasil pembuahan suami istri yang sah di luar rahim dan dilahirkan oleh istri tersebut".

KUHPerdata dan UU No. 1 Tahun 1974 yang merupakan aturan hukum positif Indonesia yang menentukan kedudukan hukum seorang anak masihlah sangat sederhana, karena di dalam Pasal tersebut tidak dipersoalkan tentang asal-usul sperma dan ovum yang dipergunakan. Tentu saja dari permasalahan di atas akan mengerucut kepada 
hubungan keperdataan antara orang tua dengan anak hasil bayi tabung dimana akan menimbulkan hubungan hukum berupa hak dan kewajiban seperti hak kewarisan terhadap anak hasil bayi tabung.

Bertolak dari pemikiran seperti itu, maka Penulis bermaksud untuk mengkaji secara komprehensif mengenai "Bayi tabung (fertilisasi in vitro) dengan menggunakan sperma donor dan rahim sewaan (surrogate mother) dalam perspektif hukum perdata"

\section{METODE PENELITIAN}

Penulisan ini menggunakan metode penulisan normatif, dilakukan dengan cara mengumpulkan dan mempelajari data yang terdapat dalam buku dan literatur, tulisantulisan ilmiah, dokumen-dokumen atau tulisan para ahli, yurisprudensi serta berbagai macam peraturan perundang-undangan. Metode pendekatan yang dilakukan yaitu pendekatan undang-undang (statute approach). Pendekatan undang-undang (statute approach) dilakukan dengan menelaah semua undang-undang dan regulasi yang bersangkut paut dengan isu hukum yang sedang ditulis.

\section{ANALISIS DAN PEMBAHASAN}

Sebagaimana kita ketahui, bahwa mulai terbentuknya janin di dalam rahim adalah ketika sel mani pria (spermatozoa) bertemu dengan sel telur wanita di dalam saluran (fallopi) menuju rahim hingga proses pembuahan sel telur dan sel mani menjadi sempurna. Kemudian, perpaduan sel telur itu terus berenang di dalam rahim hingga melekatkan dirinya pada dinding rahim, dan tetap di situ sampai sel itu (nutfah) berubah menjadi embrio ('alaqah) dan seterusnya. ${ }^{6}$

Proses pertemuan sel telur wanita dan sel mani pria yang terus bergerak pada jalurnya merupakan peristiwa natural. Akan tetapi, terkadang kita menemukan kasus dimana saluran sel (fallopi) tersumbat, sehingga sel mani tidak bisa terus berenang dan bertemu sel telur wanita. Di lain waktu, terkadang kita menemukan aib/penyakit tidak hanya berada di saluran (fallopi), tapi juga menjalar ke rahim sehingga rahim (uterus) tidak bisa mengandung janin? ${ }^{7}$

Dalam beberapa dekade terakhir, ilmu kedokteran berupaya untuk dapat mengatasi setiap penyebab yang menghalangi impian suami istri untuk mendapatkan

Adil Yusuf al-Izazy, Fiqih Kehamilan, Pasuruan: Hilal Pustaka, t.th, h. 119.

Ibid. 
keturunan. Salah satu buah kerja keras dari para ahli dan peneliti kedokteran yang menjadi andalan dalam mengatasi infertilitas (ketidaksuburan) adalah inseminasi buatan.

Ada beberapa teknik inseminasi buatan yang telah dikembangkan dalam dunia kedokteran, salah satunya adalah dengan teknik Fertilisasi in Vitro (FIV), atau masyarakat biasa menyebutnya dengan bayi tabung. Secara bahasa Fertilisasi In Vitro terdiri dari dua suku kata yaitu Fertilisasi dan In Vitro. Fertilisasi berarti pembuahan sel telur wanita oleh spermatozoa pria, In Vitro berarti di luar tubuh. Dengan demikian, fertilisasi in vitro berarti proses pembuahan sel telur wanita oleh spermatozoa pria (bagian dari proses reproduksi manusia), yang terjadi di luar tubuh. ${ }^{8}$

Pada proses bayi tabung, sel telur matang yang dihasilkan oleh sistem reproduksi istri akan dipertemukan dengan spermatozoa suami dalam sebuah cawan berisi cairan khusus di laboratorium. Cairan yang digunakan untuk merendam serupa dengan cairan yang terdapat dalam tuba wanita dengan tujuan untuk membuat suasana pertemuan antara sel telur matang dan spermatozoa senormal mungkin. Dengan demikian, keaktifan gerak spermatozoa dan kondisi sel telur dapat terjaga. ${ }^{9}$

Proses pembuahan sel telur oleh spermatozoa akan terjadi di dalam cawan tersebut, dan selanjutnya dari pembuahan tersebut akan menghasilkan embrio. Setelah embrio sudah berusia cukup (Pada umumnya 2 sampai dengan 3 hari) maka akan ditanamkan kembali ke dalam rahim sang ibu. Embrio tersebut diharapkan terus tumbuh dan berkembang hingga menjadi bayi yang pada akhirnya dilahirkan oleh sang ibu. ${ }^{10}$

Latar belakang dilakukannya bayi tabung dibagi menjadi 2 bagian, yaitu ${ }^{11}$ :

a. Faktor pria

- Gangguan pada saluran keluar spermatozoa.

- Kelumpuhan fisik yang menyebabkan pria tidak mampu melakukan hubungan seksual (misalnya kelumpuhan pada bagian pinggang ke bawah setelah terjadi kecelakaan).

- Sangat terbatasnya jumlah spermatozoa yang mampu membuahi sel telur (yang memiliki bentuk tubuh spermatozoa normal dan bergerak secara aktif).

- Hal lain yang masih belum dapat dijelaskan secara ilmiah.

\footnotetext{
Wiryawan Permadi et al, Loc. Cit.

9 Tono Djuantono et al, Hanya 7 Hari Memahami Infertilitas, Bandung: Refika Aditama, 2008, h. 59.

10 Ibid, h. 60.

11 Wiryawan Permadi et al, Op. Cit, h.4.
} 
b. Faktor wanita

- Gangguan pada saluran reproduksi wanita (seperti pada perlengketan atau sumbatan tuba).

- Adanya antibodi abnormal pada saluran reproduksi wanita, sehingga menyebabkan spermatozoa pria yang masuk ke dalamnya tidak mampu bertahan hidup.

- Hal lain yang masih belum dapat dijelaskan secara ilmiah.

Proses pelaksanaan bayi tabung dapat dilakukan dalam beberapa tahap yaitu:

a. Tahap stimulasi/perangsangan produksi sel telur matang

Salah satu penyebab sulitnya seorang wanita memiliki anak, adalah kegagalan ovarium dalam menghasilkan sel telur matang yang siap untuk dibuahi oleh spermatozoa. Kerja sistem reproduksi senantiasa dipengaruhi oleh kadar hormon reproduksi. Kadar hormon reproduksi senantiasa berubah, sesuai dengan proses yang terjadi dalam siklus ovulasi dan organ reproduksi wanita, seperti proses produksi dan pematangan sel telur dalam ovarium, maupun penebalan dinding dalam rahim.

Pada tahap awal dari proses bayi tabung, dokter akan memberikan pengobatan yang berguna untuk menciptakan kadar hormon seks/reproduksi yang sesuai demi tercapainya proses ovulasi sel telur matang pada istri. Dengan berbekal pengetahuan tentang kadar hormon yang sesuai dalam siklus produksi dan pelepasan sel telur matang, dokter akan memberikan obat dan memantau efek obat secara kontinyu pada istri.

b. Tahap pengambilan sel telur matang dan ovarium wanita dan spermatozoa pria.

Penilaian kematangan sel telur dilakukan dengan menggunakan deteksi USG. Untuk lebih memastikan, terkadang dokter juga melakukan perhitungan kadar hormon estrogen dalam darah suami atau istri. Kadar hormon estrogen yang mencapai nilai minimal $200 \mathrm{pg} / \mathrm{ml}$, menunjukkan folikel sel telur yang telah matang. Prosedur pengambilan sel telur yang telah matang/ovum pick up suami atau istri akan dilakukan dalam ruang operasi. Tentunya suami atau istri akan dibius total saat prosedur ini dilakukan.

Teknik yang biasa dilakukan oleh dokter untuk melakukan ovum pick up, adalah Transvaginal Directed Oocyte Recavery. Dengan teknik ini dokter akan 
melakukan pengambilan sel telur dari ovarium di bawah panduan gambar yang dihasilkan oleh alat USG. Sperma yang mengandung spermatozoa suami diambil melalui masturbasi atau prosedur pengambilan khusus diruang operasi. Selanjutnya, spermatozoa yang terkandung dalam sperma, akan dipisahkan dari kandungan bahan-bahan sperma lainnya. Setelah proses pemurnian ini selesai, spermatozoa yang memiliki kualitas baik, akan dipertemukan dengan sel telur matang untuk proses pembuahan.

c. Tahap pembuahan sel telur oleh spermatozoa di laboratorium.

Inilah tahap yang dinanti oleh spermatozoa dan sel telur untuk bertemu. Di dalam sebuah tempat khusus yang menjamin nutrisi, serta sterilitas, spermatozoa dan sel telur dipertemukan. Sebanyak +20.000 spermatozoa pria, ditempatkan bersama-sama dengan sel telur matang wanita dalam sebuah cawan khusus. Dengan melakukan hal ini, para ahli medis mengharapkan terjadinya proses pembuahan sel telur oleh spermatozoa dalam waktu 17-20 jam pasca pengambilan sel telur dari ovarium istri.

Setelah terjadinya pembuahan, embriologis dan dokter ahli kesuburan akan melakukan pengawasan khusus terhadap perkembangan embrio. Embrio yang dinilai berkembang dengan baik akan diberitahukan kepada pasangan suami istri untuk segera ditanamkan dalam rahim. Biasanya embrio yang baik akan terlihat berjumlah 8-10 sel pada saat ditanamkan dalam rahim.

d. Tahap pencangkokan embrio ke dalam rahim.

Embrio yang dinilai berkualitas baik, akan segera ditanamkan pada hari ke-2, ke-3, atau hari ke-5 pasca pengambilan sel telur. Pilihan hari ditanamkannya embrio, disesuaikan dengan hasil penilaian kualitas embrio pada hari-hari tersebut. Sebelum melakukan penanaman embrio, dokter akan menunjukkan hasil perkembangan hasil embrio dan mendiskusikannya dengan pasangan suami istri. Salah satu hal yang terpenting dalam diskusi dengan dokter, adalah mendiskusikan jumlah embrio yang akan ditanamkan.

Apabila jumlah embrio yang berhasil dihasilkan, lebih dari pada jumlah embrio yang akan ditanamkan, maka sisa embrio akan disimpan beku untuk menjaga kemungkinan ditanamkan dikemudian hari. Setelah mencapai kesepakatan mengenai jumlah embrio yang ditanamkan, dokter akan segera melaksanakan tugasnya untuk menanamkan embrio dalam rahim. Sama halnya 
dengan proses pengambilan sel telur dari ovarium istri, penanaman embrio akan dilakukan dalam ruang khusus. Terjadi tidaknya kehamilan pasca penanaman embrio, akan dipantau melalui kadar Human Chorionic Gonadotropin (HCG) dalam darah. Biasanya hal ini dilakukan apabila tidak terjadi menstruasi selama 16 hari.

Ada tujuh macam metode yang digunakan dalam bayi tabung, yaitu ${ }^{12}$ :

a. Sel sperma suami disuntikkan langsung ke sel telur (ovum) istri. Sperma seorang suami diambil lalu diinjeksikan langsung pada tempat yang sesuai dalam rahim sang istri sehingga sperma itu akan bertemu dengan sel telur yang dipancarkan sang istri dan berproses dengan cara yang alami sebagaimana dalam hubungan suami istri. Kemudian setelah pembuahan itu terjadi, dia akan menempel pada rahim sang istri. Cara ini ditempuh, jika sang suami memiliki problem sehingga spermanya tidak bisa sampai pada tempat yang sesuai dalam rahim.

b. Sel sperma berasal dari suami, sel telur (ovum) berasal dari istri kemudian ditanamkan ke dalam rahim istri.

Sel sperma suami dan sel telur istrinya diambil dan keduanya diletakkan di dalam saluran eksperimen (tabung), lalu diproses secara fisika hingga sel sperma suami mampu membuahi sel telur istrinya di tabung eksperimen. Lantas, setelah pembuahan terjadi, pada waktu yang telah ditentukan, sperma tersebut dipindahkan kembali dari tabung ke dalam rahim istrinya sebagai pemilik sel telur, agar sel mani yang telah mengalami pembuahan dapat melekat pada dinding rahim hingga ia berkembang dan memulai kehidupannya seperti janin-janin lainnya. Pada akhirnya si istri dapat melahirkan bayi secara alami. Anak itulah yang sekarang dikenal dengan sebutan bayi tabung. Metode ini ditempuh, apabila si istri mandul akibat saluran fallopi tersumbat. Yakni, saluran yang menghubungkan sel telur ke dalam rahim.

c. Sel sperma berasal dari donor, sel telur (ovum) berasal dari istri kemudian ditanamkan ke dalam rahim istri

Sperma seorang lelaki (sperma donor) diambil lalu diinjeksikan pada rahim istri sehingga terjadi pembuahan di dalam rahim, kemudian selanjutnya

12 Sri Wahyuni, Loc. Cit 
menempel pada dinding rahim sebagaimana pada cara pertama. Metode digunakan karena sang suami mandul, sehingga sperma diambilkan dari lelaki lain.

d. Sel sperma berasal dari suami, sel telur (ovum) berasal dari donor kemudian ditanamkan ke dalam rahim istri

Pembuahan sel secara eksternal (di dalam tabung) yang berlangsung antara sel sperma yang diambil dari suami dan sel telur yang diambil dari indung telur wanita lain yang bukan istrinya (kini disebut donatur). Kemudian, pembuahan lanjutan diproses di dalam rahim istrinya. Mereka menempuh metode kedua ini, ketika indung telur milik istrinya mandul (tidak berproduksi), tapi rahimnya sehat dan siap melakukan pembuahan (fertilisasi).

e. Sel sperma berasal dari donor, sel telur (ovum) berasal dari donor kemudian ditanamkan ke dalam rahim istri

Pembuahan sel secara eksternal (di dalam tabung) yang berlangsung antara sel sperma pria dan sel telur wanita yang bukan istrinya, kemudian pembuahan bertempat di dalam rahim wanita lain yang telah bersuami (ada 2 wanita sukarelawan). Mereka menempuh metode ketiga ini ketika indung telur wanita yang bersuami tersebut mandul, tapi rahimnya tetap sehat, demikian pula suaminya juga mandul. Kedua pasangan suami istri yang mandul ini sangat menginginkan anak.

f. Sel sperma berasal dari suami, sel telur (ovum) berasal dari istri kemudian ditanamkan ke dalam rahim wanita lain (rahim sewaan)

Pembuahan sel secara eksternal (di dalam tabung) antara 2 bibit sel milik suami-istri, lalu proses pembuahannya dilangsungkan di dalam rahim wanita lain yang siap mengandung. Metode keempat ini ditempuh, ketika pihak istri tidak mampu hamil karena ada kendala di dalam rahimnya, tetapi indung telurnya tetap sehat dan bereproduksi atau ia tidak mau mengandung dan meminta wanita lain supaya mengandung anaknya.

g. Sel sperma berasal dari suami, sel telur (ovum) berasal dari istri kemudian ditanamkan ke dalam rahim istri lainnya.

Pelaksanaan metode ketujuh ini sama dengan metode keenam, hanya saja wanita yang ditunjuk sebagai sukarelawan yang bersedia mengandung itu adalah istri kedua dari suami wanita pemilik sel telur, sehingga istri kedua yang 
mengalami kehamilan dan proses pembuahan. Metode ketujuh ini tidak berlaku di negara-negara yang hukumnya melarang poligami dan hanya berlangsung di negara-negara yang melegalisasi poligami.

\section{Kedudukan hukum anak yang dilahirkan melalui proses bayi tabung menggunakan sperma suami}

Dalam Pasal 250 KUHPerdata dijelaskan tentang pengertian anak sah, yaitu Anak sah adalah tiap-tiap anak yang dilahirkan atau ditumbuhkan sepanjang perkawinan, memperoleh si suami sebagai bapaknya. Selanjutnya dalam pasal 42 UU Nomor 1 Tahun 1974 menjelaskan bahwa "Anak sah adalah anak yang dilahirkan dalam atau sebagai akibat dari perkawinan yang sah". Kemudian dalam Pasal 99 KHI menjelaskan bahwa anak sah adalah anak yang dilahirkan dalam atau akibat perkawinan yang sah dan anak hasil pembuahan suami istri yang sah di luar rahim dan dilahirkan oleh istri tersebut.

Pengertian anak sah yang disebutkan dalam ketiga aturan tersebut bertitik tolak dari hasil hubungan seksual yang dilakukan secara alami antara pasangan suami-istri dan pasangan suami-istri tersebut terikat dalam perkawinan yang sah. Sedangkan hal-hal yang berkaitan dengan intervensi manusia (dokter), misalnya dalam membantu pasangan suami-istri yang mandul menurut penulis hanya diakomodir oleh ketentuan KHI dan belum diakomodir KUHPerdata dan UU Perkawinan.

Permasalahannya kemudian adalah apabila upaya yang dilakukan oleh pasangan suami-istri yang mengikuti program bayi tabung yang menggunakan sperma dan ovum dari pasangan suami-istri, kemudian embrionya ditransplantasikan ke dalam rahim istri berhasil memperoleh anak, bagaimanakah kedudukan hukum anak tersebut? apakah anak tersebut dapat dikualifikasi sebagai anak sah atau tidak.

Apabila ditinjau dari Konsep KUHPerdata dan UU Nomor 1 Tentang Perkawinan, sperma dan ovum yang digunakan serta tempat embrio ditransplantasikan di atas, maka nampaklah bahwa:

a. anak itu secara biologis anak dari pasangan suami-istri;

b. yang melahirkan anak itu adalah istri dari suami;

c. Orang tua anak itu terikat dalam perkawinan yang sah.

Dengan demikian, dapat dikatakan bahwa anak yang dilahirkan melalui teknik bayi tabung yang menggunakan sperma dan ovum dari pasangan suami-istri kemudian embrionya ditransplantasikan ke dalam rahim istri secara hukum dapat dikualifikasikan 
sebagai anak sah. Oleh karena anak itu dilahirkan dalam perkawinan yang sah; sperma dan ovum dari pasangan suami-istri; serta yang mengandung dan melahirkan adalah istri dari suami yang bersangkutan. Sedangkan intervensi teknologi adalah semata-mata untuk membantu proses pembuahannya saja, yang dalam pembuahan tersebut terjadi dalam tabung gelas yang proses selanjutnya tetap berada dalam rahim istri yang sah.

Berikut ini dikemukakan beberapa pendapat dan pandangan teoritis dan praktis di bidang hukum mengenai kedudukan hukum anak yang dilahirkan melalui proses bayi tabung yang menggunakan sperma dan ovum dari pasangan suami-istri yang sah kemudian embrionya ditransplantasikan ke dalam rahim istri yang bersangkutan.

Bismar Siregar mengemukakan bahwa

"Lahirnya keturunan melalui bayi tabung bukan sesuatu yang haram, tetapi kebolehan, dengan syarat dan ketentuan benih dari suami, lahannya rahim istri. Kedudukan anaknya sah. Sedangkan di luar itu haram tergolong perzinahan, jangan memasyaratkan".13

Alasan Bismar Siregar mengemukakan kedudukan hukum anak yang dilahirkan melalui proses bayi tabung yang menggunakan sperma suami adalah anak sah, oleh karena ciri insan beriman dalam hal ia beragama Islam, ia percaya penuh terhadap apa yang terjadi atas dirinya tidak lain adalah ketentuan Tuhan-Nya.

Apabila diperhatikan terhadap apa yang dikemukakan oleh Bismar Siregar jelaslah bahwa di dalam menentukan kedudukan hukum bayi tabung yang menggunakan sperma suami, lahannya rahim istri adalah kebolehan bukan haram, dan kedudukan anaknya adalah sah. Hal ini bertitik tolak pada ajaran agama Islam yang bersumber pada Al Quran dan Al Hadis, yang mana prosedur bayi tabung sama halnya dengan proses terbentuknya manusia secara alami. Kemudian yang diartikan dengan kebolehan dalam hukum Islam adalah sesuatu yang tidak dilarang dalam agama, tidak berdosa dan tidak berpahala jika dikerjakan atau ditinggalkan.

Pandangan di atas senada dengan apa yang dikemukakan oleh Sudikno Mertokusumo dan Purwoto S. Gandasubrata.

Sudikno Mertokusumo mengemukakan bahwa:

Dengan lahirnya teknologi canggih yang menghasilkan bayi tabung, sepasang suami-istri yang tidak mempunyai anak dan menginginkannya makin lama akan makin lebih suka memperoleh bayi tabung daripada mengangkat orang lain (hal ini tergantung pada pendidikan dan kesadaran). Kedudukan yuridis bayi tabung pun

13 Bismar Siregar, Bayi Tabung Ditinjau dari Aspek Hukum Pancasila, h. 5. 
seperti halnya anak angkat, yaitu "menggantikan" atau sama dengan anak kandung. Jadi anak yang dilahirkan melalui bayi tabung hak dan kewajibannya sama dengan anak kandung. Ia berhak atas pemeliharaan, pendidikan dan warisan orangtuanya. ${ }^{14}$

Sedangkan menurut Purwoto S. Gandasubrata, bahwa:

Hukum di Indonesia sebenarnya telah memberikan jalan kepada sepasang suamiistri yang tidak dikaruniai anak-keturunan untuk menggunakan lembaga hukum: mengangkat anak/ adopsi, anak piara, anak pungut, anak asuh, dan sebagainya untuk mengisi kekosongan dalam hidup kekeluargaan/ rumah tangganya. Selain itu dapat pula ditempuh cara lain yang mungkin dirasakan kurang terpuji, yakni berpoligami secara baik dengan persetujuan istri yang mandul, apabila hukumnya membenarkan hal itu ataupun dengan melakukan "kawin kontrak" khusus untuk memperoleh anak yang kurang manusiawi. Namun apabila jalan hukum itu tidak ingin ditempuhnya, maka proses "bayi tabung" yang menggunakan ovum berasal dari pasangan suami-istri dan embrionya dipindahkan ke rahim istri itulah yang masih dapat diterima/ dipertanggung jawabkan sebagai "pintu darurat" yang menurut hukum dan mungkin menurut agama masih dapat dibenarkan". ${ }^{15}$

Pada prinsipnya ketiga pendapat dan pandangan di atas menyetujui penggunaan teknik bayi tabung yang menggunakan sperma dan ovum dari pasangan suami-istri kemudian embrionya ditransplantasikan ke dalam rahim istri dan kedudukan hukum anak tersebut adalah sebagai anak sah.

Berbeda dengan konsep KUHPerdata dan UU Perkawinan yang belum mengakomodir secara jelas kedudukan hukum anak yang dilahirkan melalui proses bayi tabung (pembuahan di luar tubuh), KHI menjelaskan secara tegas kedudukan hukum anak yang dilahirkan melalui proses bayi tabung yang menggunakan sperma suami.

Pasal 99 Kompilasi Hukum Islam mendefinisikan anak sah sebagai

a. Anak yang dilahirkan dalam atau akibat perkawinan yang sah.

b. Hasil pembuahan suami-istri yang sah di luar rahim dan dilahirkan oleh istri tersebut.

Dari ketentuan pasal di atas dapatlah disimpulkan bahwa Kompilasi Hukum Islam memandang anak yang dilahirkan melalui proses bayi tabung dengan menggunakan sperma suami dikualifikasi sebagai anak sah. Hal ini didasarkan kepada pengertian anak sah yang didefinisikan oleh Pasal 99 KHI huruf b yaitu "hasil pembuahan suami-istri yang

\footnotetext{
14 Sudikno Mertokusumo, Bayi Tabung Ditinjau dari Hukum, Makalah Seminar Bayi Tabung, Yogyakarta: FKUGM, 1990, h.3.

15 Purwoto S. Gandasubrata, Perkembangan Teknologi Reproduksi Baru dan Implikasi Hukumnya, Jakarta: ISWI, 1989 , h.7.
} 
sah di luar rahim dan dilahirkan oleh istri tersebut".

Dengan lahirnya anak hasil bayi tabung, maka anak ini mempunyai hak dan kewajiban yang sama dengan anak yang dilahirkan secara alami. Masalah hak dan kewajiban antara orang tua dan anak diatur dalam Pasal 45 sampai dengan Pasal 49 UU Nomor 1 Tahun 1974 tentang Undang-Undang Pokok Perkawinan. Ditentukan bahwa orang tua wajib memelihara dan mendidik anak mereka sebaik-baiknya, sampai anak itu kawin atau dapat berdiri sendiri dan terus walaupun perkawinan antara orang tua putus (Pasal 45 UU Nomor 1 Tahun 1974). Selain kewajiban itu, orang tua menguasai pula anaknya sampai anak berusia 18 tahun atau belum pernah kawin. Kekuasaan itu juga meliputi untuk mewakili anak tersebut mengenai segala perbuatan hukum di dalam dan di luar pengadilan (Pasal 47 UU Nomor 1 Tahun 1974).

\section{Kedudukan hukum anak yang dilahirkan melalui proses bayi tabung menggunakan sperma donor}

Teknik bayi tabung semula dianjurkan sebagai pengobatan untuk kemandulan yang mulamula tubanya tersumbat dan hanya menyangkut pasangan suami-istri yang hidup dalam perkawinan yang sah. Namun dalam perkembangannya metode ini juga dapat membantu pasangan suami-istri yang kemandulannya disebabkan karena sel mani (spermatozoa) dari suami dalam air mani sangat kurang (azzzozpermia), yaitu dengan menggunakan sperma donor.

Apabila metode ini dilakukan oleh pasangan suami-istri yang mandul, maka anak yang dilahirkan nantinya akan menimbulkan persoalan dibidang hukum. Munculnya persoalan di bidang hukum terhadap anak yang dilahirkan melalui proses bayi tabung yang menggunakan sperma donor adalah disebabkan karena di satu sisi anak itu lahir dalam ikatan perkawinan yang sah tetapi di sisi lain benihnya berasal dari orang lain (donor). Sehingga nantinya akan dikenal 2 (dua) macam ayah, yaitu ayah yuridis dan ayah biologis.

Dengan demikian, apakah seorang anak yang dilahirkan melalui proses bayi tabung dengan menggunakan sperma donor dapat dikualifikasi sebagai anak sah (Pasal 250 KUHPerdata) atau dianggap sebagai anak luar kawin. Pertanyaan ini menimbulkan 2 (dua) macam jawaban, yaitu: pertama bahwa anak itu sebagai anak sah melalui pengakuan dan jawaban yang kedua bahwa anak itu sebagai anak luar kawin.

Alasan yang dapat dikemukakan bahwa anak itu sebagai anak sah melalui 
pengakuan adalah bahwa sebelum penggunaan sperma donor itu yang berbentuk preembrio itu seorang istri harus mendapat izin dari suaminya. Karena tanpa izin suaminya itu maka ia dapat menyangkal tentang keabsahan anak yang dilahirkan oleh istrinya, dan ia dapat menuduh istrinya melakukan perzinaan. Dengan demikian izin suami dalam penggunaan sperma donor mempunyai makna yang sangat penting dalam menentukan sah atau tidaknya anak yang dilahirkan oleh istrinya.

Seperti yang telah disinggung sebelumnya, masalah anak sah diatur dalam Pasal 250 KUHPerdata dan Pasal 42 UU Nomor 1 Tahun 1974. Pasal 250 KUHPerdata berbunyi "Tiap-tiap anak yang dilahirkan atau ditumbuhkan memperoleh si suami sebagai bapaknya”. Selanjutnya Pasal 42 UU Nomor 1 Tahun 1974 menjelaskan "Anak sah adalah anak yang dilahirkan dalam atau sebagai akibat perkawinan yang sah".

Apabila kita menggunakan pasal ini dalam menentukan kedudukan hukum anak yang dilahirkan melalui proses bayi tabung yang menggunakan sperma donor maka jelaslah bahwa anak itu dikatakan sebagai anak sah. Oleh karena dikandung dan dilahirkan dalam ikatan perkawinan yang sah. Lebih lanjut untuk menentukan kedudukan hukum anak yang dilahirkan melalui proses bayi tabung dengan menggunakan sperma donor apakah sesuai dengan Pasal 250 KUHPerdata atau tidak (berkedudukan sebagai anak sah), maka dapat diterapkan dengan menggunakan Pasal 285 KUHPerdata tentang pengakuan terhadap anak.

Pasal 285 KUHPerdata menjelaskan:

"Pengakuan yang dilakukan sepanjang perkawinan oleh suami atau istri atas kebahagiaan anak luar kawin, yang sebelum kawin olehnya diperbuahkan dengan seorang lain daripada istri atau suami itu, maupun anak-anak yang dilahirkan dari perkawinan mereka".

Pasal di atas menentukan bahwa anak yang diakui oleh pasangan suami-istri adalah seorang anak yang sebelum mereka kawin dibenihkan atau diperbuahkan (fertilisasi) oleh orang lain. Pengakuan itu harus dilakukan (1) menurut ketentuan undang-undang atau (2) pengakuan itu dilakukan dalam akta perkawinan.

Dengan menggunakan argumentum a contrario, maka ketentuan yang tercantum dalam Pasal 285 KUHPerdata dapat diterapkan terhadap anak yang dilahirkan melalui teknik bayi tabung yang menggunakan sperma donor. Kalau dalam Pasal 285 KUHPerdata ditentukan bahwa anak yang diakui oleh pasangan suami-istri adalah anak yang dibenihkan atau diperbuahkan (fertilisasi) oleh orang lain sebelum mereka kawin, maka 
dalam pelaksanaan bayi tabung yang menggunakan sperma donor, istri menerima sperma donor setelah pasangan suami-istri itu kawin dimana sebelum penggunaan sperma donor itu istri mendapat izin dari suaminya. Dengan adanya persetujuan tersebut maka secara diam-diam suami mengakui anak yang berasal dari donor sebagai anaknya. ${ }^{16}$

Bertitik tolak dari beberapa uraian sebelumnya, maka dapat dikemukakan bahwa kedudukan yuridis anak yang dilahirkan melalui teknik bayi tabung yang menggunakan sperma donor dengan adanya izin dari suami adalah anak sah melalui pengakuan. Apabila penggunaan sperma donor itu tidak mendapat izin dari suaminya, maka anak itu dikualifikasi sebagai anak luar kawin, karena suami dapat menyangkal tentang keabsahan anak yang dilahirkan oleh istrinya itu.

Di dalam Pasal 44 UU Nomor 1 Tahun 1974 dijelaskan bahwa:

a. Seorang suami dapat menyangkal sahnya anak yang dilahirkan oleh istrinya bilamana ia dapat membuktikan bahwa istrinya telah berzina dan anak itu sebagai akibat dari perzinaan.

b. Pengadilan memberikan keputusan tentang sah/ tidaknya anak yang dilahirkan atas permintaan yang berkepentingan.

Apabila suami dapat membuktikan bahwa anak yang dilahirkan oleh istrinya adalah produk dari zina, maka anak yang dilahirkan oleh istrinya itu hanya mempunyai hubungan keperdataan dengan ibunya dan keluarga ibunya. Namun di dalam praktek pengadilan untuk membuktikan bahwa anak yang dilahirkan sebagai akibat perzinaan adalah sangat sulit dan memakan waktu yang lama, oleh karena di dalam pembuktiannya memerlukan pemeriksaan yang seksama. Tidak saja pembuktian dengan beberapa saksi, tetapi juga memerlukan pemeriksaan dari pasangan suami-istri dan anaknya.

Selanjutnya dalam konsep Kompilasi Hukum Islam, untuk mengetahui kedudukan hukum anak yang dilahirkan melalui proses bayi tabung yang menggunakan sperma donor , Pasal 99 KHI yang menjelaskan definisi anak sah. Di dalam Pasal 99 ini anak sah didefinisikan sebagai anak yang dilahirkan dalam atau akibat perkawinan yang sah dan hasil pembuahan suami-istri yang sah di luar rahim dan dilahirkan oleh istri tersebut. Apabila kita memaknai ketentuan pasal di atas, maka kedudukan hukum anak yang dilahirkan melalui proses bayi tabung dengan menggunakan sperma donor tidak dikualifikasi sebagai anak sah, melainkan sebagai anak luar nikah. Sebagai akibat

16 Salim H.S. Bayi Tabung Tinjauan Aspek Hukum. Jakarta: Sinar Grafika, 1993. 
hukumnya, anak tersebut hanyalah memiliki hubungan nasab dengan ibunya dan keluarga ibunya (Pasal $100 \mathrm{KHI})$.

\section{Kedudukan hukum anak yang dilahirkan melalui proses bayi tabung menggunakan rahim sewaan (surrogate mother)}

Persoalan lain yang muncul berkaitan dengan adanya teknik bayi tabung adalah fenomena ibu (surrogate mother) atau sering disebut dengan rahim sewaan, di mana sperma dan ovum dari pasangan suami-istri yang diproses dalam tabung kemudian ditransplantasikan ke dalam rahim orang lain, bukan ke dalam rahim istri sahnya.

Munculnya ide surrogate mother ini disebabkan karena istri tidak dapat mengandung karena kerusakan pada rahimnya atau istri sejak lahir tidak punya rahim, atau bahkan istri ingin mempertahankan tubuh yang atletis, mengingat ia adalah seorang wanita karier. Pada masa yang akan datang persoalan surrogate mother akan mengalami perkembangan yang pesat. Hal ini akan disenangi oleh istri-istri yang mementingkan karier daripada tugas sebagai ibu rumah tangga yang pada akhirnya akan mengarah ke komersialisasi rahim. Perbuatan ini sudah menyalahi kodrat sebagai manusia dimana Tuhan telah memberikan organ tubuh yang lengkap akan tetapi manusia tidak mensyukuri nikmat yang diberikan oleh Tuhan kepadanya,

Surrogate mother apabila ditinjau dari segi teknologi dan ekonomi tidak menimbulkan masalah, tetapi tidaklah demikian jika kita meninjaunya dari segi hukum. Hukum positif yang mengatur tentang surrogate mother secara khusus di Indonesia belum ada, namun apabila kita menggunakan cara berpikir argumentum a contrario maka kita dapat menerapkan Pasal 1548, 1320, dan 1338 KUHPerdata.

Pasal 1548 KUHPerdata berbunyi:

"Sewa-menyewa ialah suatu persetujuan dengan mana pihak yang satu mengikatkan dirinya kepada pihak lainnya kenikmatan suatu barang, selama waktu tertentu dan dengan pembayaran suatu harga, dan pihak yang tersebut belakangan disanggupi pembayarannya".

Berdasarkan Pasal 1548 KUHPerdata di atas, maka yang dijadikan objek dalam sewa-menyewa adalah barang yang dapat memberikan kenikmatan bagi para pihak selama waktu tertentu dan dengan pembayaran suatu harga. Dalam hal ini apakah rahim seorang perempuan dapat dijadikan dianggap suatu barang/ sebagai objek sewamenyewa atau tidak. Untuk menjawab pertanyaan tersebut, penulis menggunakan 
ketentuan Pasal 1320 KUHPerdata untuk melihat apakah syarat-syarat dalam sewamenyewa (perjanjian) rahim ini terpenuhi atau tidak.

Di dalam Pasal 1320 KUHPerdata telah diatur tentang syarat-syarat sahnya perjanjian. Bila syarat pertama dan kedua (subyektif) tidak terpenuhi, maka perjanjian itu dapat dibatalkan (vernietigbaar), sedangkan kalau syarat ketiga dan keempat tidak terpenuhi maka perjanjian itu batal demi hukum (nullandvoid).

Apabila syarat pertama dan kedua diterapkan dalam perjanjian sewa-menyewa rahim, maka perjanjian itu dapat terpenuhi karena di sini orang-orang yang terlibat atau para pihak yang mengadakan perjanjian yaitu orang tua yang menitipkan embrio dan ibu pengganti adalah orang-orang yang cakap dan sepakat melakukan perbuatan hukum. Sedangkan masalah syarat ketiga dan keempat dalam Pasal 1320 KUHPerdata dapat diterapkan dalam perjanjian sewa-menyewa rahim, karena rahim merupakan obyek yang nyata (real) yang dapat dijadikan objek perjanjian dan sebab yang halal juga dapat diterapkan karena hal ini tidak bertentangan dengan undang-undang, kesusilaan, dan ketertiban umum.

Walaupun persoalan sewa-menyewa rahim pada KUHPerdata belum ada, tetapi undang-undang sendiri memberikan kebebasan kepada para pihak untuk menentukan isi perjanjian, sebagaimana yang disebutkan dalam Pasal 1338 ayat (1) KUHPerdata yang berbunyi "Semua perjanjian yang dibuat secara sah berlaku sebagai undang-undang bagi mereka yang membuatnya". Kebebasan itu meliputi: (1) kebebasan untuk mengadakan perjanjian dengan siapa pun; (2) kebebasan untuk menetapkan isinya; (3) perlakuan dan syarat sesuai kehendak; (4) bebas untuk menentukan bentuk perjanjiannya; (5) bebas untuk memilih ketentuan undang-undang yang mana yang ia mau. Olehnya itu perjanjian sewa-menyewa rahim secara hukum dapat dikatakan sah, karena telah memenuhi syaratsyarat yang ditentukan dalam undang-undang.

Supaya perjanjian antara surrogate mother dan orang tua genetis mempunyai kekuatan mengikat, maka sebaiknya dibuatkan perjanjian tersebut di muka dan di hadapan Notaris. Adapun isi perjanjian tersebut berupa ${ }^{17}$ :

a. Kesediaan ibu pengganti untuk menerima inseminasi buatan;

b. Kesediaan ibu pengganti untuk memberi nama kepada anak/ bayi yang diperoleh dari orang tua genetis.

17 Ibid., h. 86. 
c. Kesediaan ibu pengganti untuk menyerahkan anak/ bayi kepada orang tua genetis segera setelah melahirkannya;

d. Kesediaan ibu pengganti untuk membantu penuh dalam penyelesaian prosedur-prosedur hukum keluarga berkaitan dengan status hukum yang diinginkan dan perubahan nama keluarga anaknya;

e. Kesediaan ibu pengganti untuk menerima anak/ bayi segera setelah lahir;

f. Kesediaan orang tua genetis membayar segala biaya selama masa kehamilan dan biaya kelahirannya;

g. Kesediaan orang tua genetis untuk memberikan uang jasa kepada ibu pengganti.

Sedangkan menurut Sudikno Mertokusumo ${ }^{18}$ bahwa persyaratan-persyaratan yang harus dimuat dalam perjanjian antara ibu pengganti dengan orang tua pemesan adalah misalnya mengenai imbalan jasa, bagaimanakah status anaknya nanti, bagaimana kalau ibu pengganti itu hidupnya kurang berhati-hati sehingga menyebabkan anak yang dikandungnya meninggal dunia. Selain hak-haknya, antara lain atas balas jasa dan pelayanan kesehatan yang baik, ibu pengganti juga mempunyai kewajiban, yaitu agar anak yang dikandungnya lahir sehat dan menyerahkan kepada suami-istri yang menitipkan embrio kepadanya.

Apabila diperhatikan isi perjanjian dan persyaratan-persyaratan di atas, maka nampaklah bahwa ibu pengganti harus menyerahkan anak yang dilahirkannya kepada suami-istri yang menitipkan embrio tersebut. Selain itu, ibu pengganti membantu dalam penyelesaian prosedur-prosedur hukum yang berkaitan dengan status hukum yang diinginkan dan perubahan nama keluarga anaknya. Dengan demikian dapat dikatakan bahwa kedudukan hukum anak yang dilahirkan melalui proses bayi tabung yang menggunakan sperma dan ovum dari pasangan suami-istri kemudian embrionya ditransplantasikan ke dalam rahim surrogate mother dikualifikasikan sebagai anak angkat. Oleh karena itu secara yuridis anak itu adalah anak ibu pengganti dari suaminya sedangkan secara genetis anak itu adalah anak pasangan suami-istri yang memesan.

Upaya yang dilakukan dalam kasus-kasus ibu pengganti atau permasalahan terhadap bayi tabung yang dilahirkan menggunakan rahim sewaan (surrogate mother) adalah melalui pengangkatan anak yang dilakukan oleh orang tua genetis. Apabila anak itu

18 Sudikno Mertokusumo, Op. Cit, h. 4. 
sudah diperlakukan sebagai anak angkat, maka ia mempunyai hak dan kewajiban yang sama dengan anak kandung.

Masalah anak angkat tidak diatur dalam KUH Perdata tetapi diatur dalam Stb. 1917/129 tentang Ketentuan-Ketentuan untuk Seluruh Indonesia tentang Hukum Perdata dan Hukum Dagang bagi Orang-Orang Cina. Berdasarkan bunyi Pasal 8 Stb. 1917 Nomor 129 ditentukan 4 (empat) syarat untuk mengangkat seorang anak, yaitu:

a. Adanya persetujuan dari orang atau orang-orang yang melakukan adopsi.

b. 1) Apabila yang diangkat itu seorang anak dari orang tuanya, maka diperlukan izin dari orang tua itu atau kalau salah seorang di antara mereka telah meninggal dunia dahulu, dalam hal ibu telah beralih ke perkawinan baru; dalam hal ini, seperti halnya kalau kedua orang tuanya telah meninggal dunia. Untuk adopsi seorang yang di bawah umur disyaratkan persetujuan dari walinya dan Balai Harta Peninggalan.

2) Apabila yang diadopsi itu seorang anak luar kawin, maka diperlukan izin dari orang tua yang mengakui sebagai anak. Kalau anak itu tak diakui sebagai anak harus ada persetujuan dari walinya serta dari Balai Harta Peninggalan.

c. Harus ada persetujuan dari orang yang akan diadopsi kalau anak itu sudah berumur 15 tahun.

d. Apabila yang mengangkat anak itu seorang janda, harus ada persetujuan dari saudara laki-laki dan ayah dari almarhum suaminya.

Senada dengan konsep KUHPerdata, UU No. 1 Tahun 1974 Tentang Perkawinan tidak mengatur secara tegas mengenai kedudukan hukum anak yang dilahirkan melalui proses bayi tabung menggunakan rahim sewaan (surrogate mother). Beranjak dari ketentuan Pasal 42 UU nomor 1 Tahun 1974 disebutkan bahwa "Anak sah adalah anak yang dilahirkan dalam atau sebagai akibat dari perkawinan yang sah". Pengertian ini menurut penulis bertitik tolak dari hasil hubungan seksual yang dilakukan secara alami antara pasangan suami-istri.

Dari definisi Pasal 42 UU No. 1 Tahun 1974 dapat ditarik suatu kesimpulan bahwa anak yang dilahirkan melalui proses bayi tabung menggunakan rahim sewaan tidak dikualifikasi sebagai anak sah ataupun sebagai anak luar nikah. Hal ini didasari karena tidak adanya hubungan seksual yang dilakukan oleh pasangan suami istri tersebut dalam menghasilkan seorang anak. Menurut hemat penulis, anak tersebut dikualifikasi sebagai 
anak angkat. Hal didasarkan karena pasangan suami-istri tersebut hanya mengambil/ mengangkat seorang anak dari wanita lain.

Kemudian dalam konsep Kompilasi Hukum Islam, untuk mengetahui kedudukan hukum anak yang dilahirkan melalui proses bayi tabung yang menggunakan rahim titipan (surrogate mother) dapat dilihat dari ketentuan Pasal 99 KHI yang menjelaskan definisi anak sah, yaitu anak yang dilahirkan dalam atau akibat perkawinan yang sah dan hasil pembuahan suami-istri yang sah di luar rahim dan dilahirkan oleh istri tersebut. Apabila kita memaknai ketentuan pasal di atas, maka kedudukan hukum anak yang dilahirkan melalui proses bayi tabung dengan menggunakan rahim sewaan tidak dikualifikasi sebagai anak sah dan juga bukan sebagai anak luar nikah, karena lahirnya anak tersebut tidak melalui rahim perempuan yang terikat perkawinan yang sah.

Anak yang dilahirkan dari suatu rahim dengan tidak ada akad nikah disilsilahkan kepada ibunya yang melahirkan seperti anak zina walaupun bukan hasil dari perbuatan zina, dari itu anak yang dilahirkan bukan anak si ayah yang punya sperma, dengan demikian bila ia perempuan, ayah yang punya sperma tidak berhak menjadi wali sekaligus tidak saling waris mewarisi. ${ }^{19}$

Menurut hemat penulis, anak yang dilahirkan melalui proses bayi tabung dengan menggunakan rahim sewaan dalam konsep KHI dikategorikan sebagai anak zina. Hal ini didasarkan karena dalam hal peminjaman rahim wanita untuk kandungan bayi hukumnya adalah haram, sebab setiap wanita hanya dapat dibenarkan menggunakan rahimnya untuk kandungan bayi yang berasal dari perkawinan sah, sehingga untuk anak yang dikandung dalam rahim wanita lain adalah termasuk anak zina, walaupun pelaksanaan ini tidak termasuk definisi zina, namun hukumnya sama-sama haram, hal ini disebabkan karena:

a. Merusak keturunan (nasab).

b. Mengacaukan status waris dan wali.

c. Bila anak itu lahir kelak dan terjadi suatu perselisihan kepemilikan antara kedua ibu tersebut yang berdampak psikologis yang berat.

d. Timbul permasalahan lagi kepada ibu yang mana si anak tersebut setelah ia besar, apakah ibu yang mempunyai rahim atau ibu yang mempunyai ovum. ${ }^{20}$

Rasulullah SAW bersabda: "Tidak ada dosa yang lebih besar setelah syirik kepada

\footnotetext{
19 H. M. Hasballah Thaib, Kuliah Agama dan Etika Kedokteran, Medan: Penerbit Fakultas Kedokteran Universitas Islam Sumatera Utara, 2010, h. 175.

20 Ibid, h. 174.
} 
Allah, daripada sperma yang diletakkan oleh seseorang pada rahim wanita yang tidak halal baginya." (H. R. Ibnu Abiddunya dari Al-Haitam)21. Dan selanjutnya Rasulullah SAW bersabda: "Tidak halal bagi seseorang yang beriman dengan Allah dan hari kiamat bahwa disiramkannya air (mani)-Nya kepada yang bukan ladangnya." (H. R. Abu Daud dan Tirmizi) ${ }^{22}$

\section{KESIMPULAN}

Dalam perspektif hukum perdata, anak yang dilahirkan melalui proses bayi tabung (fertilisasi in vitro) dengan menggunakan sperma donor berkedudukan sebagai anak sah apabila memperoleh pengakuan (Pasal 280 KUHPerdata), sedangkan anak yang dilahirkan melalui proses bayi tabung (fertilisasi in vitro) dengan menggunakan rahim sewaan (surrogate mother) berkedudukan sebagai anak angkat (Pasal 8 Stb. 1917/129).

\section{Daftar Pustaka}

\section{Peraturan perundang-undangan}

Kitab Undang-undang Hukum Perdata (Burgelijk Wetboek).

Undang-Undang Nomor 1 Tahun 1974 tentang Perkawinan, dimuat dalam Lembaran

Negara Republik Indonesia Tahun 1974 Nomor 1 dan Tambahan Lembaran Negara Republik Indonesia Nomor 3019.

Undang-Undang Nomor 36 Tahun 2009 tentang Kesehatan, dimuat dalam Lembaran Negara Republik Indonesia Tahun 2009 Nomor 144 dan Tambahan Lembaran Negara Republik Indonesia Nomor 5063.

Instruksi Presiden Nomor 1 Tahun 1991 tentang Kompilasi Hukum Islam

Peraturan Pemerintah Nomor 9 Tahun 1975 tentang Pelaksanaan Undang-Undang Nomor

1 Tahun 1974 tentang Perkawinan, dimuat dalam Lembaran Negara Republik Indonesia Tahun 1975 Nomor 12 dan Tambahan Lembaran Negara Republik Indonesia Nomor 3050.

Staatsblad Nomor 129 Tahun 1917 tentang Ketentuan-Ketentuan untuk Seluruh Indonesia tentang Hukum Perdata dan Hukum Dagang bagi Orang-Orang Cina.

21 H. Nukman Sulaiman, dkk, disampaikan dalam Seminar Sehari Tentang Meminjamkan Rahim Untuk Kandungan Bayi, Medan: Penerbit Yaspen UNIVA, Universitas Al-Wasliyah, 1987, h. 34

22 Ibid 


\section{Buku, jurnal, dan makalah}

al-Izazy, Adil Yusuf, Fiqih Kehamilan, Pasuruan: Hilal Pustaka.

AM, Idries, Aspek Medikolegal Pada Inseminasi Buatan/Bayi Tabung, Edisi I, Jakarta: Bina Rupa Aksara.

Budiarto, M, Pengangkatan Anak Ditinjau dari Segi Hukum, Jakarta: Akademi Presindo, 1987.

Djuantono, Tono et al, Hanya 7 Hari Memahami Infertilitas, Bandung: Refika Aditama, 2008. Gandasubrata, Purwoto S., Perkembangan Teknologi Reproduksi Baru dan Implikasi Hukumnya, Jakarta: ISWI, 1989.

Mertokusumo, Sudikno, Bayi Tabung Ditinjau dari Hukum, Makalah Seminar Bayi Tabung, Yogyakarta: FK-UGM, 1990.

Permadi, Wiryawan et al, Hanya 7 Hari Memahami Fertilisasi In Vitro, Bandung: PT Refika Aditama, 2008.

Pudjosubroto, Santoso, Masalah Hukum Sehari-hari, Yogyakarta: Hien Hoo Sing, 1964.

Qadhawi, Yusuf Al, Halal dan Haram dalam Islam, Surabaya: PT. Bina Ilmu, 1976.

Salim, Bayi Tabung Tinjauan Aspek Hukum, Jakarta: Sinar Grafika, 1993.

Siregar, Bismar, Bayi Tabung Ditinjau dari Aspek Hukum Pancasila, Makalah pada Symposium tentang "Eksistensi Bayi tabung ditinjau dari aspek Medis, Hukum, Agama, Sosiologi dan Budaya, Surakarta: FH UNISRI.

Sulaiman, Nukman, dkk, disampaikan dalam Seminar Sehari Tentang Meminjamkan Rahim Untuk Kandungan Bayi, Medan: Penerbit Yaspen UNIVA, Universitas Al-Wasliyah, 1987

Thaib, H. M. Hasballah, Kuliah Agama dan Etika Kedokteran, Medan: Penerbit Fakultas Kedokteran Universitas Islam Sumatera Utara, 2010

Thamrin, Husni, Aspek Hukum Bayi Tabung. Jogyakarta: Aswaja Pressindo.

Widyatamma, Tim, Kamus Saku Kebidanan, Jakarta: Widyatamma, 2011.

\section{Situs web}

Cinantya Rizky Dewi Santosa, S.H., “Wasiat Wajibah Bagi Anak Angkat Dalam Kompilasi Hukum Islam", http://repository.usu.ac.id/bitstream/123456789/5299/1/0201 2717.pdf,

Sri Wahyuni, "Status Hak Waris Anak Luar Kawin Menurut KHI", h.10, http://eprints. undip.ac.id/15327/1/sri wahyunib4b004176.pdf, 
M. Lathoif Ghozali, "Anak Zina dalam Pandangan Hukum Islam”, h. 15, http://ejournal. sunan-ampel.ac.id/index.php/alQanun/article/view/./pdf, 